seg stabilt. Er dette virkelig noe vi ønsker å regulere i senk? Deres andre kilde (6) undersøker «ever-users», altså alle som noen gang har prøvd e-sigaretter, men sier lite om hvor mange som blir faste brukere.

Sist, men ikke minst fortsetter den ugyldige sammenlikningen med snus. For det første er det helt meningsløst for noen som har prøvd e-sigaretter å gå over til et produkt som både smaker verre og påvirker helsa svært negativt. For det andre dokumenterer Sanner \& Grimsrud heller ikke denne gang et eneste tilfelle av noen som har gått fra å bruke e-sigaretter til å røyke sigaretter. Dette første forklarer her det andre. Jeg observerer at forfatterne ønsker å vente i mange år på dokumentasjon på en slik trend, men nå har e-sigarettene vært her såpass lenge at det burde være mulig å oppdrive ett eneste tilfelle hvis det skal være sannsynlig at dette blir en trend. For det tredje; hvis det dukker opp et og annet tilfelle som gjør nettopp dette, anser jeg det som svært sannsynlig at dette er personer som ville begynt å røyke uansett. Dette er også en stor svakhet ved påstanden om at snusbruk fører til sigarettrøyking: hva hvis snus ikke hadde vært tilgjengelig - hadde da disse personene gått rett på sigarettene? Er det snusen i seg selv som gjør at de begynner med sigaretter eller er det mer sannsynlig at disse personene er disponert for å begynne med sigaretter uansett?

\section{Morten Moe}

morten.metall@gmail.com

Morten Moe (f. 1979) er IT-konsulent i Get.

Ingen oppgitte interessekonflikter.

\section{Litteratur}

1. Sanner T, Grimsrud TK. E-sigaretter - til skade eller nytte? Tidsskr Nor Legeforen 2015; 135: 959-61

2. Fagerstrom K. Dependence on tobacco and nicotine. Nicotine science and policy 14.12. 2013. http://nicotinepolicy.net/karl-fagerstrom/ 520-dependence-on-tobacco-and-nicotine (19.8.2015).

3. Updating recommendation on smoking cessation. The myth of nicotine addiction. A letter from Professor Molimard to HSA. Form indep 26.8.2013. www.formindep.org/The-myth-of-nicotine-addiction.html (10.8.2015).

4. Anti-smoking experts paid by Big Pharma. Another article by Klaus K. Frank Davis 8.11. 2014. https://cfrankdavis.wordpress.com/2014/11/08/ anti-smoking-experts-paid-by-big-pharma/ (10.8.2015).

5. McCarthy M. «Alarming» rise in popularity of e-cigarettes is seen among US teenagers as use triples in a year. BMJ 2015; 350 (apr17 7): h2083.

6. White J, Li J, Newcombe R et al. Tripling use of electronic cigarettes among New Zealand adolescents between 2012 and 2014. J Adolesc Health 2015; 56: $522-8$.

\section{T. Sanner \& T.K. Grimsrud svarer:}

Moe reiser tvil om nikotin i seg selv er avhengighetsskapende. Nikotin er et sterkt avhengighetsskapende stoff. Nikotin oppfyller kriteriene for å klassifiseres som avhengighetsskapende og er det stoffet som utløser avhengighet ved bruk av tobakksprodukter $(1,2)$. Det er imidlertid individuelle forskjeller i evnen til å bli avhengig av nikotin. Tobakksindustrien kjente til avhengighetsproblemet på et tidlig tidspunkt og har utnyttet dette til å manipulere med tilsetningsstoffer som påvirker avhengigheten. Det er for øvrig en kjent sak at en avhengighet også kan påvirkes av psykologiske, sosiale og andre atferdsmessige forhold.

Moe er uenig når vi skriver at det er en kraftig økning i bruken av e-sigaretter blant unge mennesker. Flere undersøkelser har vist at dette er riktig. To eksempler: I New Zealand økte andelen av 14-15-åringer som hadde prøvd e-sigaretter fra 7,0\% i 2012 til $20 \%$ i 2014 (3). I Florida hadde 1,5\% av 11-13-åringer brukt e-sigaretter de siste 30 dagene i 2011. I 2014 var andelen økt til 4,0\%. For 14-17-åringene var de tilsvarende tallene 3,1 \% i 2011 og $10,8 \%$ i 2014 (4).

Moe mener at «det helt meningsløst for noen som har prøvd e-sigaretter å gå over til et produkt som både smaker verre og påvirker helsa svært negativt». Det er vel kjent fra andre typer avhengighet (alkohol, narkotika) at brukerne går over til andre produkter når tilgjengeligheten endres. I løpet av neste år må myndighetene bestemme om e-sigaretter skal selges fritt, og dersom e-sigaretter blir tilgjengelig i norske butikker, blir det neste spørsmålet om det skal være tillatt å bruke e-sigaretter på steder hvor det ikke er tillatt å røyke. Vi vet at flere røykere benytter snus på steder hvor de ikke har anledning til å røyke, og vi frykter at det samme vil være tilfellet blant brukere av e-sigaretter.

\section{Tore Sanner}

tore.sanner@kjemi.uio.no

Tom K. Grimsrud

Tore Sanner (f. 1935) er professor emeritus. Han var tidligere forskningssjef ved Institutt for kreftforskning, Radiumhospitalet, og professor II ved Kjemisk institutt, Universitetet i Oslo.

Ingen oppgitte interessekonflikter.

Tom K. Grimsrud (f. 1955) er dr.med., spesialist i arbeidsmedisin og overlege/forsker ved Kreftregisteret.

Ingen oppgitte interessekonflikter.

\section{Litteratur}

1. Dybing E, Sanner T. Nikotinavhengighet-medisinsk-biologiske forhold. Tidsskr Nor Lægeforen 2002; 122: 302-5

2. Le Foll B, Goldberg SR. Effects of nicotine in experimental animals and humans: an update on addictive properties. Handbook Exp Pharmacol 2009; 192: 335-67.

3. White J, Li J, Newcombe R et al. Tripling use of electronic cigarettes among New Zealand adolescents between 2012 and 2014. J Adolesc Health 2015; 56: 522-8.

4. Porter L, Duke J, Hennon M et al. Electronic cigarette and traditional cigarette use among middle and high school students in Florida, 2011-2014. PLoS ONE 2015; 10: e0124385.

\section{Re: E-sigaretter - til skade eller nytte?}

Debatten i forbindelse med Sanner \& Grimsruds artikkel om e-sigaretter (1) har blant annet dreid seg om skadevirkninger av nikotin. Jeg viser til en artikkel publisert av Royal Society for Public Health (2). Artikkelen tar for seg de skadevirkningene nikotin i seg selv har, og ikke som en substans i sigaretter. Da fremkommer det at nikotin i seg selv er «harmless». I artikkelen fremmes det også en rekke konkrete forslag til å få redusert forbruket av sigaretter og fremme andre mindre skadelige produkter som alternativer.

\section{Steinar Willassen}

steinwi@hotmail.com

Steinar Willassen (f. 1960) er hovedlærer ved Forsvarets Høgskole. Ingen oppgitte interessekonflikter.

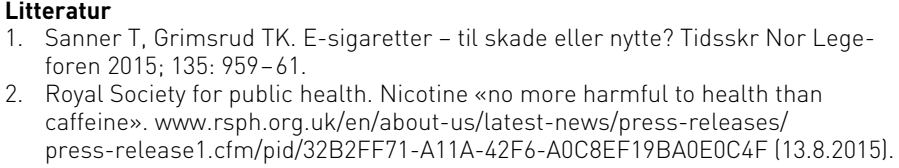

\section{T. Sanner \& T.K. Grimsrud svarer:}

Helseskadende effekter av ren nikotin på mennesker lite undersøkt. Det er viktig å være klar over at Royal Society for Public Health (RSPH) ikke er en vitenskapelig institusjon, men en medlemsorganisasjon for britiske helsearbeidere. Willassen viser i sitt innlegg til en pressemelding fra RSPH, ikke en vitenskapelig artikkel. Pressemeldingen omtaler en rapport som RSPH nylig har offentliggjort (1), og i denne rapporten er det bare én enkelt referanse som omhandler toksiske effekter av nikotin, nemlig en syv år gammel oversiktsartikkel. Det er ikke angitt hvem som har skrevet RSPH-rapporten.

Gravide kvinner og personer med nylig diagnostisert hjerteinfarkt eller hjerneslag advares mot bruk av medisinske nikotinerstatningsprodukter. Nikotin er sannsynligvis en medvirkende årsak til at brukere av tobakksprodukter har dårligere prognose ved kreftsykdom og redusert effekt av kreftbehandling (2). I tillegg mistenkes nikotin for å bidra til utvikling av type 2-diabetes (3). 